ŽELJKA FINK

Filozofski fakultet SveučIlišta u Zagrebu

ZaGREB, HRVATSKa

zfink@ffzg.hr

https://doi.org/10.17234/9789531755139.7

\title{
HRVATSKI I RUSKI FRAZEMI S KOMPONENTAMA REP I XBOCT
}

U radu se daje kontrastivna analiza hrvatskih i ruskih frazema s komponentama rep i xвocm. Prvi dio rada sadržava izraze i frazeme u širem smislu temeljene na prenesenom značenju leksema rep i хвост. U drugom se dijelu rada pažnja posvećuje zoonimskim frazemima sa sastavnicama rep i хвост u kojima je provedena potpuna ili djelomična desemantizacija, a frazemi se $\mathrm{s}$ obzirom na sliku u dubinskoj strukturi, odnosno s obzirom na motivacijski element u njoj dijele na tri skupine. Prva je motivirana slikom životinje i/ili njezina repa. Za drugu je bitno da se u dubinskoj strukturi ostvaruje odnos između životinje, odnosno njezina repa i drugog subjekta. Dubinska se struktura treće skupine temelji na načinu ponašanja životinje unutar skupine.

Ključne riječi: hrvatski jezik, ruski jezik, frazeologija, frazemi s komponentama rep $i$ хвост

1. Rep u kralježnjaka stražnji je dio tijela koji se nastavlja na trup. Sastoji se od koštane osnovice, mišića i pokrovnoga tkiva, a ima u prvom redu pokretačku funkciju. Od kralježnjaka nemaju ga žabe, neki viši majmuni i čovjek. Razvoj i funkcija repa različiti su u raznih životinja. Ribe imaju rep koji se ne odvaja oštro od trupa, ima jako mišičje i snažnu repnu peraju pa je glavni pokretački organ. Kod mnogih je kopnenih kralježnjaka rep izgubio svoju prvotnu funkciju, a kao pomoćni organ pri kretanju služi samo repatim vodozemcima i nekim gmazovima. Kod ptica je pak repni dio kralježnice reduciran na četiri do šest pršljenova koji su srasli u trtičnu kost. Rep većine sisavaca za njih nema neku presudnu ulogu. Ipak, kao završni dio tijela važan je kao organ za prihvaćanje (kod nekih širokonosnih majmuna, mravojeda, oposuma) ili kao organ za odupiranje kod nekih skakača (klokan, skočimiš), dok rogatoj stoci služi za rastjerivanje nametničkih kukaca. Na kratkom repu kitova i sirena nalazi se vodoravna peraja (za razliku od riba kod kojih je okomita), pa njihov rep ima prvotnu, pokretačku funkciju. U ranijim stadijima čovječji zametak ima rep sastavljen od sedam do osam kralježaka, ali oni poslije srastu u trtični dio kralježnice.

Rep nekih životinja prekriven je kožom; on je ponekad cijelom dužinom ili djelomično gol, dok je kod drugih prekriven krznom ili ljuskom. Kod dijela je životinja veoma dug i pokretljiv (kod majmuna), kod nekih je kratak i patrljast, a kod nekih širok i spljošten (kod dabrova, kitova). Mačke se, primjerice, koriste repom kako za održavanje ravnoteže, tako i za međusobno sporazumijevanje.

U američkim i azijskim mitovima rep mnogih životinja ima faličku ulogu. S druge pak strane, simboličko se značenje tursko-mongolskog barjaka, načinjenog od jednog repa ili više njih (najčešće konjskih, a ponekad i bivoljih ili jakovih) zasniva na vjerovanju da je upravo taj dio životinjskoga tijela ispunjen snagom. 
Prije više stotina tisuća godina čovjekovi su preci vjerojatno imali rep. On se stoga povezuje s različitim primitivnim nagonima ukorijenjenima duboko u ljudskoj psihi. Prema švicarskom psihologu C. G. Jungu, sanjati sirenu ili u snu biti sirena, odnosno sanjati neku životinju s uočljivim repom (gušter, krokodil) znak je da je osoba u vezi s najskrovitijim zakucima svoje ljudske psihe.

2. Leksemi rep і хвост slavenskoga su porijekla pri čemu je zanimljivo da se prvi upotrebljava u većem dijelu južnoslavenskih jezika dok je drugi zabilježen u istočnoslavenskim i dijelu zapadnoslavenskih jezika. ${ }^{1}$

U općim je rječnicima hrvatskoga i ruskog jezika zabilježeno nekoliko značenja leksema rep odnosno $x в о \mathrm{~cm}$. Osim leksičkih značenja u ovom će dijelu rada biti spomenute i sintagme, odnosno frazemi značenje kojih je temeljeno na nekom od rječnički registriranih prenesenih značenja ${ }^{2}$, a navodi se također i nekoliko termina u sastavu kojih su rep i xвocm.

2.1. Prvo se značenje odnosi na dio tijela sisavaca, ptica, riba, vodozemaca, zmija, kukaca. Ruski rječnici spominju još i povrće (repu ili rotkvu) donji dio kojeg ima nastavak u obliku repića (хвост редиски, хвост репь), a također dugi viseći dio nekog predmeta, naprimjer, papirnatoga zmaja (хвост бумажного змея).

Sljedeća se značenja odnose na zadnji, izduženi dio čega, pri čemu to može biti zadnji dio aviona, rakete, letjelice (гер aviona, хвост самолета), a taj je dio obično u opreci s prednjim krajem koji je također izražen somatizmom (usp. nos aviona, нос самолета).

Ruski rječnici nadalje spominju kolokvijalnu upotrebu riječi $х в о с т$ u kontekstu dugačkih odjevnih predmeta (haljine, suknje) skuti kojih se vuku po podu (платье $c$ длинным хвостом). U hrvatskom se pak razgovornom jeziku ponekad repom naziva izduženi dio odjeće posebna kroja (rep fraka).

Četvrta se skupina značenja odnosi na skupinu ljudi. Vrlo se često u obama jezicima susreću leksemi rep i хвост u značenju ljudi koji čekaju u redu da što kupe, obave itd. Takvo je preneseno značenje temeljeno na sličnosti između dugačkoga repa životinje i skupine ljudi u kojoj pojedinci stoje jedan iza drugoga. Često se upotrebljavaju izrazi u dubinskoj strukturi kojih je upravo takva skupina ljudi: stajati и rери, стоять в хвосте.

Navodimo primjere upotrebe:

Isto tako, često će sjevernjak u svoje ruke preuzeti i financijsko poslovanje obitelji, pa mu neće biti teško stajati u repu u banci ili na pošti da bi platio račune - što svaki normalan južnjak nastoji izbjeći... (Vijenac, 2014.)

$1 \quad$ Osim u hrvatskom leksem rep potvrđen je u srpskom, bosanskom i slovenskom. U ruskom se pak i u bjeloruskom upotrebljava leksem xвост, a u ukrajinskom - xвicm (gen. xвоста). U češkom je jeziku rječnički registrirano nekoliko leksema semantički ekvivalentnih hrvatskomu rep (chvost, ocas, ohon) dok se u slovačkom registrira leksem chvost. Za razliku od navedenog, u bugarskom i makedonskom upotrebljava se опашка, a u poljskom - ogon.

2 Navode se i tri značenja iz hrvatskog jezika nezabilježena u rječnicima, ali je njihova upotreba potvrđena u različitim izvorima. 
Когда подходил троллейбус, одни стояли в хвосте, другие проталкивались локтями. (НКРЯ, Солженицын)

Drugi se aspekt navedenoga značenja znatno šire i češće upotrebljava u ruskom jeziku. On se odnosi na ljude koji se kreću na kraju neke kolone, odreda (двигаться 6 хвосте отряда). U sličnom se kontekstu rep može upotrijebiti i u hrvatskom jeziku (iako to značenje nije zabilježeno u rječnicima), npr. u repu kolone od pedesetak vozila. U ruskom se pak jeziku leksem $x$ вост potvrđuje u široj upotrebi u značenju 'zadnji dio с̌еga': хвост поезда, хвост каравана. Ovaj prijenos značenja nije temeljen samo na sličnosti s dijelom tijela životinje nego i na položaju na njezinu tijelu.

I upravo je taj aspekt u kojem je presudni sem „,na kraju čega“ sudjelovao u stvaranju značenja ruskoga frazema $в$ хвосте ('iza svih'). Frazem se najčešće upotrebljava s glagolima tipa идти, плестись, оставаться, оставлять:

Себя он считает вожаком стаи, в которую включил всю семью, причем мы с Борисом плетемся где-то в хвосте. (НКРЯ, Рубина)

Так что же, так и допустим, чтоб соседи наши рекорд побили, нас в хвосте оставили? (ФСРЯ, Горбатов)

Za razliku od toga u hrvatskom je jeziku u frekventnoj upotrebi frazem biti (naći se i sl.) na repu događaja u kojem se obavezno nakon komponente rep dodaje imenica u genitivu da bi se jasnije naglasio prijenos značenja dviju imeničkih sastavnica. Značenje frazema je 'biti na posljednjem (najgorem) mjestu, biti (naći se) izvan zbivanja, ne znati što se događa, ne biti ni o čemu obaviješten' gdje se najvažniji element značenja odnosi na lošu poziciju u čemu ili u okviru čega, odnosno na potpunu neobaviještenost o čemu. Važan je i element omalovažavanja predmeta o kojem se govori - to može biti neka institucija, ukupnost duhovnih dobara ili pak neka osoba.

Primjeri upotrebe navedenog frazema:

Kao i u svakoj zemlji u krizi, kultura je na repu događaja. (HFR, N)

Mora li teatar uvijek kaskati na repu događaja. (HFR, Šnajder)

Ja sam se kao i obično našao na repu događaja i nisam ni o čemu imao pojma.

$(\mathrm{HFR}, \mathrm{N})$

Svakako treba spomenuti i značenje zabilježeno u ruskim rječnicima u kojem je riječ o nezavršenom dijelu kakva posla. Navedeno je leksičko značenje sudjelovalo u formiranju frazeološkoga u jedinici оставить / оставлять хвосты <за собой> koji ima i potpuni ekvivalent u hrvatskom jeziku ostaviti / ostavljati repove <iza sebe (za sobom) >. Treba ipak naglasiti da se to leksičko značenje ne fiksira u hrvatskim rječnicima pa možemo govoriti o frazeološki vezanom značenju. Oba frazema imaju značenje: 'ne završiti / ne završavati poslove, ostaviti / ostavljati <iza sebe (za sobom) > nezavršen posao (poslove)'. 
Primjeri upotrebe navedenog frazema:

Катюша, привет! А можно всю сумму оплатить; не люблю хвосты за собой оставлятьь. sp39.ru>viewtopic.php... (posjet 3. 5. 2014.)

Ispričavala se da joj se žuri. Sređivala je papire. Nije htjela ostaviti repove, kako je govorila. (HFR, Majdak)

Svaka vlast koja dugo traje ostavi iza sebe neke "repove” koje treba raščistiti. (HNK)

U hrvatskom se jeziku u bliskom frazeološki vezanom značenju upotrebljava i sastavnica rep u negativno konotiranom frazemu vuku se repovi za kim gdje se imenička komponenta odnosi na neke neriješene probleme iz prošlosti: 'ostala su neriješena (neraščišćena) pitanja iz prošlosti, nisu zaboravljeni stari grijesi (pogreške)':

\section{Znamo svi kakvi se repovi vuku za njim i to će naši politički protivnici itekako znati}

iskoristiti. (Novi list, 2012.)

U ruskom je jeziku, međutim, zabilježeno još jedno podznačenje iz studentskog žargona u kojem je riječ o nepoloženim ispitima ili kolokvijima: иметь хвост по немецкому, сдать хвост по химии. Na osnovi toga značenja nastao je i žargonizam хвостист, a rabi se u odnosu na studenta koji nije na vrijeme izvršio sve studentske obaveze.

Ruski rječnici bilježe upotrebu riječi $x в о \mathrm{~cm}$ i u značenju izduženog dijela dima ili prašine koji se vide iznad zemlje (черный хвост дыма, длинный хвост пыли). Јеdan se aspekt toga značenja odnosi i na svijetlu prugu koju za sobom ostavlja kometa (хвост кометы), a u tom se značenju (iako nezabilježenom u rječnicima) ponekad susreće i riječ rep u hrvatskom jeziku (rep komete).

U ruskim je rječnicima zabilježeno i jedno terminološko značenje, a imenica se tada upotrebljava u množini: хвосты. To su otpaci koji ostaju nakon obogaćivanja rude.

2.2. Leksemi rep i xвосm ušli su i u sastav termina iz različitih područja. Navodimo samo neke od njih.

U obama se jezicima tip frizure naziva konjski rep, odnosno конский хвост.

Smatra se da je konjski rep jedna od najstarijih frizura u ljudskoj povijesti, a najraniji poznati zapisi datiraju iz 1600. godine pr. Kr. Riječ je o antičkim freskama koje pokazuju žene u Staroj Grčkoj koje vežu kosu u rep, a taj se trend potom proširio te su ga s vremenom prihvatile i Rimljanke. Nije, međutim, u svim dijelovima svijeta konjski rep smatran ženskom frizurom. Na taj su se način češljali samo muškarci, pripadnici drevnog naroda Maja, dok su njihove žene plele pletenice, a robovi bili kratko ošišani. Tek je u 18. st. konjski rep postao omiljenom frizurom među muškarcima u Europi. Tijekom 20. st. nosile su ga djevojčice, a posebnu je popularnost doživio 1959. kad se na tržištu pojavila prva lutka Barbie s kosom začešljanom u rep. Filmske dive poput Audrey Hepburn i Brigitte Bardot doprinijele su masovnoj popularizaciji toga tipa frizure među odraslim ženama. 
U hrvatskom se jeziku biljka gavez (Symphytum) naziva još i konjski rep ${ }^{3}$. Gavez je rod s oko 25 vrsta zeljastih biljaka iz porodice oštrolista (Boraginaceae). Cvjetovi žute, modre ili purpurno-crvene boje skupljeni su u kovrčice. Gavez raste u Srednjoj Europi na vlažnim mjestima - u jarcima, uz vodu i na vlažnim livadama. U pučkoj se medicini zbog ljekovitoga korijena upotrebljava za zacjeljivanje rana, kod krvarenja, loma kostiju. Djelotvoran je u liječenju bolesti probavnih organa, katara želuca.

Ruski se termin щучий хвост odnosi na biljku pod nazivom sanseverija ili sansevierija (Sansevieria), biljni rod s približno 60 do 70 vrsta zeljastih sukulenata i polugrmova koje pripadaju porodici ljiljana ili, prema nekim autorima, porodici agava. Podrijetlom je iz Afrike i jugoistočne Azije, a neke vrste - iz Australije. Njihovi dugi čvrsti vlaknasti listovi skupljeni su u ružicu. Listovi nekih vrsta imaju svijetli obrub, neki pak imaju bijele, odnosno tamnozelene pruge ili pjege na plojci, a mogu biti dulji od metra.

Lastin rep (Papilio machaon) dnevni je leptir iz porodice lastinrepaca (Papilionidae). Na prednjim mu krilima prevladava žuta boja i crn širok rub, dok su stražnja krila šiljasto produljena. S duljinom od $6 \mathrm{~cm}$ ubraja se među najveće europske leptire. Nastanjuje otvorene prostore gotovo cijele Europe. Hrani se nektarom. U Hrvatskoj je zaštićen zakonom o zaštiti prirode.

Valja spomenuti frazem u koji je kao sastavnica uklopljen navedeni termin iz lepidopterologije: nestati (izgubiti se) u vidu lastina repa. Frazem ima poredbenu strukturu jer prijedložni izraz $u$ vidu ima značenje 'u obliku čega, poput'. Značenje mu je 'iznenada nestati, neprimjetno se izgubiti'.

Navode se sljedeći primjeri upotrebe:

Kad su oni vidjeli da im se približavamo, nestali su u vidu lastina repa! www.

forum.hr/showthread.php?t=486002\&page $=4$ (posjet 18. 3. 2014.)

I, naravno, dok sam vikao crven u licu, on je sa sretnim smiješkom opleo po gasu

i izgubio se u vidu lastina repa. (Slobodna Dalmacija, 2014.)

3. Daljnji će dio rada biti posvećen hrvatskim i ruskim zoonimskim frazemima sa sastavnicama rep i хвост u kojima je provedena potpuna ili djelomična desemantiza$\mathrm{cija}^{4}$. Frazemi se s obzirom na dubinsku strukturu odnosno s obzirom na motivacijski element u njoj mogu podijeliti na tri skupine.

3.1. Prva je motivirana slikom životinje $\mathrm{i} /$ ili njezina repa. U prvom se dijelu navode frazemi s uključenim zoonimom i somatizmom, u drugom - oni sa somatizmom ili somatizmima.

\footnotetext{
Ostali nazivi za tu biljku su crni gavez, kilnjak, veliki gavez, korijen za slomljenu nogu, gabež, opašica, svatovci, vela konsolida.

$4 \quad$ U analizu nisu uključeni dijalektni, žargonski i arhaični frazemi.
} 
3.1.1. Hrvatski poredbeni frazem lijepa kao mačka ispod repa može se upotrijebiti kao ironični komentar ili primjedba vezana za izgled neke djevojke ili žene. Često se, međutim, u tekstu pojavljuje i kao replika obično ispunjena samoironijom u situaciji kad netko izgovara kompliment tipa „danas si baš lijepa“. Za frazem je karakteristična rima. Valja, ipak, naglasiti da u njemu nije osnovni somatizam rep, nego upravo onaj na koji se aludira i zbog njega je značenje frazema ironično te se on definira antonimom pridjeva u A-dijelu.

Zanimljivo je spomenuti prisjećanje jedne djevojke koja je upotrijebila taj frazem obraćajući se odgojiteljici u vrtiću:

Ja sam svojoj teti u vrtiću rekla da je lijepa kao mačka ispod repa, misleći, naravno, reći joj kako je jako lijepa :))) 13.11.2005. - 15:33 h trillian.blog.hr/ arhiva-2005-11.html (posjet 18. 3. 2014.)

Veoma se slična slika pojavljuje u stilski sniženom ruskom frazemu ncy (собаке) nод хвост u kojem se, za razliku od hrvatskoga, kao sastavnica pojavljuje zoonim pas. I tu prijedložno-imenička sastavnica nод хвост služi kao aluzija na neizgovoreni somatizam. Dva su značenja frazema. Prvo se odnosi na situaciju u kojoj je nešto bespotrebno izgubljeno, uzaludno potraćeno. Drugim se izražava podcjenjivački odnos prema čemu.

Primjeri upotrebe navedenog frazema:

Сначала он остолбенел, потом стал пыхтеть от ярости, потом схватил сборник и стал ожесточенно листать его («две недели собаке подхвост, две недели дураикой работы, две драгоиенные недели... »). (НКРЯ, Парийская) Так что все твои пережсивания - псу под хвост. (НКРЯ, Геласимов)

Za razliku od prethodno spomenutih frazema u kojima su zabilježeni zoonimi pas i mačka, u sljedećem se kao sastavnica pojavljuje krava: imati jezik kao krava rep. U tom se frazemu s poredbenom strukturom duljina kravljega repa uspoređuje s jezikom, koji ovdje simbolizira brbljavost. U nekim je kontekstima riječ samo o osobama koje mnogo i nezaustavljivo govore, dok se u drugima govori i o neprimjerenom i nepristojnom načinu komunikacije. Stoga se kao njegov sinonim mogu navesti frazemi imati dug jezik i imati oštar jezik.

Primjer upotrebe navedenog frazema:

Kakvim ćeš ti građanskim odgojem učiti đake kad si ti neodgojen i bezobrazan! Imaš jezik ko krava rep! http://www.novilist.hr/Vijesti/Hrvatska/JovanovicGradanskim-i-zdravstenim-odgojem-reducirat-cemo-obolijevanje-ovisnost-inasilje (posjet 18. 3. 2014.)

Valja spomenuti i ruski rečenični frazem s ornitonimom сорока на хвосте принесла <что> koji se upotrebljava u situaciji kad ne želimo odati izvor informacije. 
Iako svraka često simbolizira brbljavost, ovdje je, čini se, presudan za sliku i formiranje značenja upravo dugačak rep. On se može smatrati donositeljem nekog podatka, novosti, informacije:

- Откуда ты это знаешь? - Сорока на хвосте принесла! (НКРЯ, Житков)

U hrvatskom se jeziku u posljednje vrijeme u navedenom kontekstu rabi kalk iz engleskoga ptičica je rekla komu što (engl. a little bird told me $<$ so $>$ ).

Zanimljivo je spomenuti i hrvatski frazem ima koga kao kusih (kusatih) pasa ('velik je broj koga, ima mnogo (mnoštvo) $\left.k o g a^{\prime}\right)^{5}$ u kojem se zapravo negira rep (komponente kus i kusat znače 'koji je bez repa, kojemu je rep odrezan ili znatno skraćen').

Primjer upotrebe navedenog frazema:

Otkad sam upala u akvarijske vode vidim da nas ima ko kusih pasa, pa mi nije jasno kako to da nema časopisa o akvaristici... www.akvarijske-ribe.com/.../ viewtopic.php?... (posjet 19. 3. 2014.)

3.1.2. Zasebnu podskupinu čine frazemi u kojima se ne pojavljuje zoonim kao sastavnica, već samo somatizmi rep i xвосm. Veći dio takvih frazema sadržava dva somatizma.

U hrvatskim frazemima drugi somatizam je glava, pa su tako zabilježene jedinice: bez glave $i$ repa je što, nema <ni> glave ni repa što, ima glavu $i$ rep što. U njima se somatizmi smatraju krajnjim točkama životinjskoga tijela, oni označavaju početak i kraj, čine zaokruženu cjelinu, pa se, čini se, logičan prijenos značenja usmjerio prema postojanju ili nepostojanju smisla, smislene zaokruženosti u nekom tekstu, govoru, pripovijedanju. Stoga se prva dva frazema, u kojima se negira postojanje dvaju dijelova tijela, odnose na nešto nesređeno i nesuvislo, dok treći ima antonimno značenje. Nešto se šire upotrebljava frazem ne moći uhvatiti ni za glavu ni za rep koga, što u kojem je sem shvaćanja, odnosno neshvaćanja presudan za formiranje značenja.

Navodimo nekoliko primjera upotrebe tih frazema:

A ne bi to ni bio toliki davež da njegovo pripovijedanje nije bilo obično nesuvislo trabunjanje bez glave i repa. (Brešan)

Ova priča (...) nema ni glave ni repa, da o nekoj poruci i ne govorimo. (HFR, Kvesić)

Ovaj put ti sastav i nije toliko loš: bar ima glavu i rep. (HFR)

Uvijek izmiču s onim glavnim, ne možeš ih uhvatiti ni za glavu ni za rep. (HFR, Barković)

Zanimljivo je spomenuti da se zoonimski frazem $\mathrm{s}$ istim značenjem upotrebljava i u ruskom, razlika je u tome što se tamo pridjevska komponenta odnosi na nekastrirane pse: как собак нерезаных. 
U ruskom se frazemu $\langle u>$ в хвост и в гриву, u kojem se nalaze somatizmi rep i griva, također zaokružuje u cjelinu tijelo životinje, ali se značenje usmjerava prema intenzivnosti djelovanja, a, prema podacima iz rječnika, glagoli koji se najčešće pojavljuju kao kolokati su oni tipa бить, лупить, погонять:

Гоняли их в хвост и в гриву 50 тысяч километров! (НКРЯ, Лепин)

Я лупил их в хвост и в гриву, от души, старательно и со вкусом. (НКРЯ, Белянин)

Итак, насущное дело - еда... Еду американскую ругать принято в хвост и в гриву. (НКРЯ, Песков, Стрельников)

Primjeri iz raznih tekstova potvrđuju, međutim, znatno širu upotrebu navedenog frazema, npr.

Артистов снимали в хвост и в гриву. (НКРЯ, Козаков)

Ruski frazem вожжа под хвост попала кому uključuje samo somatizam хвост. U njegovoj je dubinskoj strukturi sadržana slika repa ispod kojeg je dio opreme za upravljanje. Konj, ispod čijeg je repa dospio taj dio opreme, postaje nemiran i nervozan. Takav se način ponašanja i takvo stanje prenosi na čovjeka pa frazem ima značenje 'duševno nestabilan je $t k o$, neuravnotežen (mušičav, hirovit) je $t k o$ '.

Primjer upotrebe navedenog frazema:

Бывает, попадет вожжа под хвост, с самого утра, и настроение ужасное, и ты под это дело возьмешь и поссоришься со своим лучшим другом, самым лучшим. И думаешь: «Ну, ё-моё, ну хватит уже с ним дружить, двадиать лет продружили, и хватит! pasitivv.beon.ru>13615-273...vozhzhapod-hvost... (posjet 9. 5. 2014.)

3.2. U drugoj se skupini u dijelu frazema pojavljuje isključivo somatizam, dok dio uključuje i zoonim. Za nju je bitno da se u dubinskoj strukturi ostvaruje odnos između životinje, odnosno njezina repa i drugog subjekta, tj. taj drugi subjekt na neki način stupa u odnos sa životinjom.

3.2.1. U prvoj se podskupini kao sastavnica nalazi somatizam, a odnos između repa i drugog subjekta realizira se na različite načine.

Spomenimo prvo dva hrvatska frazema u kojima se odnos između somatizma i drugog subjekta ostvaruje udaranjem po repu: dati po repu komu ('ukoriti koga, kritizirati koga') i dobiti / dobivati po repu ('biti <oštro> ukoren (iskritiziran), dobiti / dobivati ukor'). U tim je jedinicama vidljiv drugačiji odnos subjekta i objekta, tj. u prvom se frazemu polazi od drugog subjekta prema repu, dok je u drugom važniji rezultat udaranja. 
Pogledajmo primjere upotrebe navedenih frazema:

Tada su mi neki najviši dužnosnici HDZ-a htjeli “dati po repu”, ali sam argumentirano dokazao da sam u pravu. (Slobodna Dalmacija, 2002)

Prvi put kada je podviknuo na glavnu tužiteljicu zbog neargumentiranog napada, dobio je po repu od „racionalnog“ Račana i bio skinut kao „persona non grata“ s mjesta koordinatora hrvatske vlade za Haag. (Nacional, 2007)

Sljedeći frazemi su hrvatski stati na rep komu, čemu i njegov ruski ekvivalent прижать (прищемить) хвост кому, чему ('doskočiti komu, čemu, spriječiti koga, što $u$ čemu, zaustaviti koga, što, nadmudriti koga') u kojima dubinska struktura sugerira gaženje ili pritiskanje repa.

Primjeri upotrebe navedenih frazema:

Svi su rogoborili protiv nevidljive pošasti, ali nisu joj mogli stati na rep. spektator.

blogspot.com/.../ivana-rogar.html (posjet 25. 4. 2014.)

Поймать его - значит прищемить хвост генералу, что само по себе приятно... (НКРЯ, Галицкий)

Sličnu dubinsku strukturu ima ruski frazem наступить / наступать на хвост кому s dvama značenjima '1. sustići / sustizati koga, biti za petama komu; 2. strogo (oštro) postupiti / postupati prema komu'.

Primjeri upotrebe frazema:

- Кажется, ведь за нами никто не гонится, неприятель не наступает нам на хвост, отчего же, спрашивается, такой беспорядок? (ФСРЛЯ, СергеевЦенский)

Если я кому-то наступил на хвост (а такое могло быть: порой в интересах фирмы я придерживался очень жесткой политики), то вряд ли эти люди стали бы прибегать к таким радикальным мерам. (НКРЯ, Трофимова)

Veoma je blizak prvom značenju prethodnoga frazema i ruski висеть на хвосте у кого (u značenju 'sustizati koga, pratiti u stopu koga, biti za petama komu') dubinska struktura kojega sadržava sliku osobe obješene o rep životinje.

Primjer upotrebe frazema:

Между прочим, «тупье» вполне могли пешком броситься за транспортером в погоню, и хотя Гош выюал из аппарата иельх тридиать километров в час, уверенности, что враг не висит на хвосте, у диверсанта не было. (НКРЯ, Дивов) 
U ruskom se jeziku upotrebljava i frazem motiviran slikom grubog zavrtanja repa: накрутить хвост (хвоста) кому sa značenjem 'psovati (grditi) koga na pasja kola, grubo psovati koga'.

Primjer upotrebe frazema:

И вновь Василий Семенович начал просматривать стремительно растущую бумажную стопку в надежде обнаружить, ради чего все-таки Сергей Сергеевич Полозков так накрутил хвост своему подчиненному. (НКРЯ, Галицкий)

Ruski frazem sa slikom kraćenja, podrezivanja repa - укоротить хвост кому ima značenje 'navesti koga da se ne precjenjuje, staviti koga na njegovo pravo mjesto'. Temeljem slike u dubinskoj strukturi može se pretpostaviti da dulji rep osigurava samopouzdanje i sigurnost.

Primjer upotrebe frazema:

- Давно пора Андриану Брежневу хвост укоротить, - более задористыли и весельми словами поддержал предложение Коренковой Николай Шаталов. (ФСРЛЯ, Лаптев)

Veoma je zanimljiv slučaj hrvatskoga i ruskog frazema s jednakom slikom u dubinskoj strukturi, a različitim značenjem: staviti soli na rep komu і насыпать соли на хвост кому. U njima se osim somatizama rep i хвост pojavljuje i imenička komponenta sol (соль). Hrvatski se frazem odnosi na situaciju u kojoj uzalud pokušavamo koga nadmudriti, odnosno pokušavamo uhvatiti nekoga tko je izvan dohvata, dok ruski znači 'prirediti neugodnost komu, dovesti koga u neugodan položaj'.

Primjeri upotrebe navedenih frazema:

Prša je rekao da će se za Francuza malo raspitati. Vraga će se raspitati ako ovaj danas odlazi. Možeš mu staviti soli na rep. (Ugrešić)

- Вот те и пролетария! - зло сказал он... - А тебе пролетарий соли на хвост насыпал? - язвительно спросил Коваль. (ФСРЛЯ, Либединский)

3.2.2. U frazeme druge podskupine uključen je zoonim (zanimljivo je da je u obama jezicima riječ o mačku) i somatizam rep $($ хвост).

$\mathrm{U}$ dubinskoj strukturi frazema s rečeničnom strukturom veži (objesi) to mačku o (na) rep ili možeš vezati (objesiti i sl.) mačku za (o) rep što (u značenju 'sve je to uzalud, okani se toga, ništa ne vrijedi što, možeš prekrižiti što') životinji se na rep stavlja nešto nepotrebno, nepoželjno. Značenjem frazema izražava se jasan podcjenjivački odnos prema takvu „obješenu“ predmetu što se može ilustrirati sljedećim primjerima upotrebe: 
Mi smo pobijedili na izborima, mi odlučujemo, objesite vi svoju demokraciju mačku o rep. (HNK)

A vi mi tu dimite na pulmologiji! Ja ću vas smjesta i neopozivo prijaviti primarijusu Šlausu! - I što?! I što?! - izdere se ona na njega. - On će mi za kaznu ukinuti zračenje?! Ili će mi izvaditi i drugo plućno krilo? Mladi idiote, možete svoje blesave prijetnje okačiti mačku za rep! (Tribuson)

Još je jedan par lažnih prijatelja potvrđen u ovoj skupini. Hrvatski frazem povući / vući mačka za rep ima značenje 'izvrgnuti se / izvrgavati se opasnosti, nepotrebno izazvati / izazivati neprilike samom sebi' ${ }^{6}$ i u njemu je bitan sem rizika i opasnosti. U ruskom je, za razliku od hrvatskoga, u obama značenjima presudan sem odugovlačenja - тянуть кота за хвост sa značenjem '1. odugovlačiti s odgovorom izazivajući pritom ljutnju i nezadovoljstvo sugovornika; 2. odugovlačiti s poslom, predugo obavljati kakav posao'. Iako se kreće od jednake slike u dubinskoj strukturi frazema u obama jezicima, od povlačenja za rep, veoma je zanimljivo da je taj postupak izazvao različite asocijacije kod dvaju naroda.

Navodimo primjere upotrebe:

Pazi da me ne izazivaš, ne povlači mačka za rep da ne dobiješ batine. (HFR)

Tb говори конкретнее, а не тяни кота за хвост! (НКРЯ, Мельник)

... впервые за последние четыре года никто не сможет теперь упрекнуть

парламентариев в том, что они тянут кота за хвост и продлевают сессии по причине малой эффективности своей работьл. (НКРЯ, Чернов)

3.3. Dubinska se struktura treće skupine temelji na načinu ponašanja životinje unutar skupine (čopora), pri čemu se odnos između nadređenih i podređenih životinja, a jednako tako mjesto na hijerarhijskoj ljestvici svake od tih životinja ogleda kroz položaj repa.

Kao ilustracija za ovu skupinu poslužit će, kao prvo, hrvatski frazem dignuti / dizati rep i njegov potpuni ruski ekvivalent задрать / задирать хвост. Podignut je rep u životinjskom svijetu znak dominacije i može biti predznak napada. Tako se ponašaju dominantni mužjak ili ženka koji su sigurni u sebe i svoju snagu i koji ne žele nikome prepustiti svoj položaj na hijerarhijskoj ljestvici. Iz toga vrlo logično proizlazi značenje frazema u obama jezicima: 'umisliti se / umišljati se, uzoholiti se'.

To se potvrđuje u sljedećim primjerima upotrebe:

Čim je dobio to nasljedstvo, digao je rep i napustio stare prijatelje. (HFR)

Чем настойчивее и живее старалась услужить ей мать, тем враждебнее чуждалась ее бабушка. Как-то она, красная от огня и печи, крикнула ей:

$\overline{6}$ U hrvatskom se jeziku upotrebljava i frazem povući / vući (potegnuti / potezati) vraga za rep s jednakim značenjem, ali on se ovdje ne uključuje u analizu jer ne sadržava zoonim. 
- Ты чего это больно хвост-то задираешь, невестка? ... Аль от мужа храбрости набралась? (ФСРЛЯ, Гладков)

Slično značenje temeljeno na samouvjerenom ponašanju proizlazi iz dubinske strukture ruskog rečeničnog frazema держи хвост пистолетом (трубой, морковкой) $\mathrm{u}$ kojem se nazire oblik visoko uzdignuta repa. Zbog imperativnog oblika glagolske komponente $^{7}$ cijeli frazem dobiva značenje savjeta kojim se osobu ohrabruje i potiče da ne zdvaja i ne pada duhom.

Primjeri upotrebe:

Не дергайся - служба сопливых не любит. Словом, держи хвост пистолетом. Я соглашался, а все же - поташнивало. (НКРЯ, Зорин)

- Слушай их, Фотий Иваныч, - сказал Галаган, - а делай все наоборот. Три к носу, держси хвост трубой. (НКРЯ, Владимов)

Suprotno se ponašanje životinje ogleda kroz rep uvučen između nogu. On pokazuje prihvaćanje nižeg položaja u čoporu. Životinja zauzima takav stav u nazočnosti dominantnog mužjaka ili ženke. Oba jezika bilježe frazeme koji su nastali kao rezultat opisanog načina ponašanja: podviti (podvući) rep, поджать (подвернуть) хвост, pri čemu se njihovo značenje također podudara s refleksnom reakcijom životinje: 'uzmaknuti, povući se, postati svjestan svoje slabosti'.

To se ogleda i u primjerima upotrebe:

U romanu «Živi i mrtvi» Konstantin Simonov opisuje ljude koji u miru izgledaju $i$ govore karizmatično, hrabro, no kad dođe do gustog, podviju rep. (Gjoni)

Бродский поджал хвост. На блоге Бродского началась настоящая истерика по поводу предстоящего привлечения его владельца к ответу за клеветнические высказывания. skuns.info $2010 / 12$ /brodskij-podzhal-hvost/ (posjet 25. 4. 2014.)

U obama se jezicima često u upotrebi susreće i priložni frazem nastao na temelju spomenutoga glagolskog - podvijena rера, с поджатым хвостом ('priznajući poraz, sa sviješću o svojoj slabosti'):

Zvonko nije htio tek tako prihvatiti poraz, povući se podvijena repa pred najvećim neprijateljem. (Naprta)

Если уйдешь с поджатым хвостом, словно побитая собака, мне будет за тебя стылно...http://7days.ru/caravan/2014/7/andre-agassi-kak-obygrat-sudbu/20\#ixzz36X4mNhN3 (posjet 25. 4. 2014.)

$\overline{7}$ U manjem se dijelu ruskih rječnika glagolska sastavnica donosi u infinitivu, pa frazem postaje glagolski. 
Još je jedan hrvatski frazem vezan za tematsko polje podređenosti: uvlačiti se (zavlačiti se) pod rep komu. Riječ je o životinji koja se osjeća slabijom i prihvaća svoj niži položaj u hijerarhiji te se ponekad prema dominantnoj jedinki može ponašati na način izražen u semantičkom talogu. Takav se postupak prenosi na značenje frazema koje govori o ulagivanju ili laskanju osobi na višem položaju. To se potvrđuje i u sljedećim primjerima upotrebe:

Izgubio je svako ljudsko dostojanstvo uvlačeći se pod rep bogatunima. (HFR, N) Te ulizice, koje se svakom na vlasti zavlače pod rep, otkrile su svoje pravo lice. $(\mathrm{HFR}, \mathrm{N})$

Veoma blisko značenje ima i ruski frazem вилять хвостом ${ }^{8}$ u kojem se u dubinskoj strukturi pojavljuje drugačija slika (mahanje repom). ${ }^{9}$ To se vidi u sljedećem primjeru upotrebe:

Что же заставляет всех этих людей так униженно вилять хвостом перед человеком, который даже и не взглянет на них никогда внимательно. (ФСРЯ, Куприн)

U hrvatskom se pak jeziku također upotrebljava slikovno identičan frazem mahati repom sa značenjem 'umiljavati se, udvarati se, ulagivati se' ${ }^{10}$. Iako se navedeni frazem relativno rijetko susreće u suvremenim tekstovima, čini se da se on u njima realizira $u$ drugačijem značenju:

Mislim da nema čovjeka kojem srce ne zakuca brže kad se dohvati kofera. Sama pomisao na bujicu novih saznanja, doživljaja i dojmova koje nosi svaki susret s drugim nacijama i kulturama čini me sretnim kao malo dijete. Samo kaj ne mašem repom! http://www.jutarnji.hr/template/article/article-print.jsp?id=207624 (posjet 5. 5. 2014.)

Jednom prilikom kad sam se raspitivao za zvučnike dobijem u ruke neku malu laganu kutijicu što se zove HRT i ispadne da mi točno to treba. Kune se trgovac da je dobro, ja mu povjerujem i uzmem najjeftiniji model. I tako je završilo ... zvuč-

$\overline{8} \quad$ Frazem ima i drugo značenje ('izmicati od čega koristeći se lukavošću') koje nije relevantno za temu rada.

9 Zanimljivo je da frazeme s jednakom slikom u dubinskoj strukturi (вертеть хвостом, крутить хвостом) ruski rječnici različito definiraju. Tako, naprimjer, Fedorovljev frazeološki rječnik spomenuto značenje navodi kao jedno od triju značenja uz frazem вертеть хвостом, dok Frazeološki rječnik u redakciji Molotkova registrira frazem вертеть (крутить) хвостом, ali ne bilježi ovdje spomenuto značenje. Taj pak rječnik ovdje analizirano značenje veže uz frazem вилять хвостом.

10 Frazem i navedeno značenje zabilježeno je u Frazeološkom rječniku hrvatskoga ili srpskog jezika J. Matešića. 
nici sviraju, nije ispalo preskupo, ja mašem repom. http://www.audiofil.hr/forum/ forum_posts.asp?TID=12265\&PID=389620 (posjet 5. 5. 2014.)

Dobio sam gitaru za Guitar Hero i sad mašem repom od sreće :-) PS: Hvala ti još jednom na poklonu. solvox.blogspot.com/.../dobio-sam-gitaru-za-guitar-hero-isad.html (posjet 5. 5. 2014.)

Iz navedenih se tekstova može vidjeti da se frazem upotrebljava kad se opisuje stanje sreće, zadovoljstva i dobrog raspoloženja. I to je u skladu s općom percepcijom značenja mahanja repom, iako valja nadodati da je takva percepcija najvjerojatnije nastala na temelju ponašanja psa. ${ }^{11}$

Vidjeli smo da u frazemima treće skupine izostaje zoonimska komponenta. Možemo li ipak pretpostaviti o kojoj je životinji riječ? Općenito se može reći da se u frazemima kao sastavnica najčešće nalazi neka životinja iz najbližeg okruženja; to su one koje su živjele u seoskom dvorištu ili u neposrednoj čovjekovoj blizini. Čovjek ih je promatrao i svoje vizualno iskustvo prenosio u male žanrovske oblike, pa tako i u frazeme. Kako je pas prva životinja koju je prije nekih 12.000 godina čovjek domesticirao, lako je zaključiti da je njegovo ponašanje postalo model koji je s vremenom ušao u dubinsku strukturu frazema. Kad je pak riječ o njegovu repu, znamo da je on pokazatelj društvenog položaja pasa, njihova raspoloženja. Rep služi kao signal drugim jedinkama iz skupine, a jednako tako pas i čovjeku u čijoj blizini živi položajem repa prenosi informacije o svojem raspoloženju. Pogledamo li dubinsku strukturu frazema treće skupine, vidjet ćemo da je naše znanje o položaju repa pasa i o podacima koje pas prenosi drugim jedinkama u skupini (ali i ljudima) utjecalo na formiranje značenja pojedinih frazema.

4. U radu su kontrastivnom metodom analizirani hrvatski i ruski frazemi s komponentama rep i xвосm. Prvi dio sadržava izraze i frazeme u širem smislu značenje kojih je temeljeno na prenesenom značenju leksema rep i xвосm. Drugi je dio rada posvećen analizi 18 hrvatskih i 16 ruskih zoonimskih frazema kod kojih je provedena djelomična ili potpuna desemantizacija, a oni su podijeljeni u tri skupine s obzirom na motivacijski element i sliku u dubinskoj strukturi.

11 Treba ipak napomenuti da mahanjem repom životinja, tj. pas, prenosi različite informacije ovisno o intenzitetu mahanja, o tome u kojem smjeru maše itd. S druge strane, druge vrste životinja mahanjem repom prenose drugu vrstu informacija (usp. takav način ponašanja kod mačaka). 


\section{LITERATURA}

Barčot, Branka. 2014. Divlja životinja kao sastavnica u hrvatskoj, ruskoj i njemačkojfrazeologiji. Doktorska disertacija. Filozofski fakultet. Sveučilište u Zagrebu. Zagreb.

Hordy 2010 = Горды, Мирослава. 2010. Соматическая фразеология современных русского и польского языков. Щецин: Volumina.pl.

Hrnjak, Anita. 2001. O mogućnostima konceptualne i/ili tematske organizacije i obrade frazeologije. Filologija. 36-37: 189-200.

Menac-Mihalić, Mira. 2007. Hrvatski dijalektni frazemi sa sastavnicom mačak, mačka, mače i sl. U: Zbornik Matice srpske za filologiju i lingvistiku. L. Mladenović, Aleksandar (red.). Novi Sad: Matica srpska. 505-516.

Menac-Mihalić, Mira. 2007. O nekim hrvatskim dijalektnim frazemima sa zoonimskom sastavnicom. U: Kulturni bestijarij. Marjanić, Suzana; Zaradija Kiš, Antonija (red.). Zagreb: Institut za etnologiju i folkloristiku - Hrvatska sveučilišna naklada. 389-400.

Vidović Bolt, Ivana. 2011. Životinjski svijet u hrvatskoj i poljskoj frazeologiji I. Zagreb: Hrvatska sveučilišna naklada.

Visković, Nikola. 2009. Kulturna zoologija. Što je životinja čovjeku i što je čovjek životinji. Zagreb: Naklada Jesenski i Turk.

\section{RJEČNICI I PRIRUČNICI}

Anić, Vladimir. 2003. Veliki rječnik hrvatskoga jezika. Zagreb: Novi Liber.

Bierich et al. 2005 = Бирих, Александр К. et al. 2005. Русская фразеология. Историко-этимологический словарь. Москва: Астрель - АСТ - Люкс.

Bol’šoj tolkovyj slovar' russkogo jazyka 1998 = Большой толковый словарь русского языка. 1998. Кузнецов, Сергей А. (ред.). Санкт-Петербург: Норинт.

Chevalier, Jean; Gheerbrant, Alain. 1989. Rječnik simbola. Mitovi, sni, običaji, geste, oblici, likovi, boje, brojevi. Zagreb: Nakladni zavod Matice hrvatske.

Colin, Didier. 2004. Rječnik simbola, mitova i legendi. Zagreb: Naklada Ljevak.

Etimologičeskij slovar' sovremennogo russkogo jazyka 2008 = Этимологический словарь современного русского языка. 2008. Фатеева, Л. И. (ред.). Москва: АСТ: Восток Запад.

Fedorov 2007 = Федоров, Александр И. ${ }^{3} 2007$. Фразеологический словарь русского литературного языка. Москва: АСТ - Астрель. [ФСРЛЯ]

FSRJ 2006 = Фразеологический словарь русского языка. 2006. Молотков, Александр И. (ред.). Москва: Астрель - АСТ. [ФСРЯ]

Gluhak, Alemko. 1993. Hrvatski etimološki rječnik. Zagreb: August Cesarec.

Hrvatska enciklopedija. sv. 4, Fr - Ht. 2002. Zagreb: Leksikografski zavod Miroslav Krleža.

Hrvatska enciklopedija. sv. 6, Kn - Mak. 2004. Zagreb: Leksikografski zavod Miroslav Krleža.

Hrvatska enciklopedija. sv. 9, Pri - Sk. 2007. Zagreb: Leksikografski zavod Miroslav Krleža. 
Matešić, Josip. 1982. Frazeološki rječnik hrvatskoga ili srpskog jezika. Zagreb: IRO „Školska knjiga“.

Menac, Antica; Fink-Arsovski, Željka; Venturin, Radomir. 2003. Hrvatski frazeološki rječnik. Zagreb: Naklada Ljevak. [HFR]

Menac, Antica et al. 2011. Hrvatsko-ruski frazeološki rječnik. Zagreb: Knjigra.

Mokienko; Nikitina 2008a = Мокиенко, Валерий М.; Никитина, Татьяна Г. 2008. Большой словарь русских народных сравнений. Москва: ОЛМА Медиа Групп.

Mokienko; Nikitina 2008b = Мокиенко, Валерий М.; Никитина, Татьяна Г. 2008. Большой словарь русских поговорок. Москва: ОЛМА Медиа Групп.

Ožegov; Švedova 1994 = Ожегов, Сергей И.; Шведова, Наталия Ю. 1994. Толковый словарь русского языка. Москва: АЗЪ.

Rječnik hrvatskoga jezika. 2000. Šonje, Jure (red.). Zagreb: Leksikografski zavod Miroslav Krleža - Školska knjiga.

Rusko-hrvatski ili srpski frazeološki rječnik. 1979, 1980. Menac, Antica (red.). Zagreb: IRO „Školska knjiga“.

Skok, Petar. 1973. Etimologijski rječnik hrvatskoga ili srpskoga jezika. sv. 3, poni² - Ž. Zagreb: Jugoslavenska akademija znanosti i umjetnosti.

Šanskij 1975 = Шанский, Николай M. et al. 1975. Краткий этимологический словарь русского языка. Москва: Просвещение.

Vasmer 1987 = Фасмер, Макс. 1987. Этимологический словарь русского языка. том IV, Т - Ящур. Москва: Прогрес.

\section{Mrežni izvori:}

Hrvatski nacionalni korpus http://www.hnk.ffzg.hr/ [HNK]

http://hr.wikipedia.org/wiki/Gavez Datum posjeta: 13. 3. 2014.

http://www.budi.in/beauty/konjski-rep-jednostavna-frizura-koja-ne-izlazi-iz-mode-3967 Datum posjeta: 13. 3. 2014.

Kotenkova 1988/9 = Котенкова, Елена В. 1988/9. Чей хвост лучше? http://biolib.narod.ru/ zoo/tail.pdf Datum posjeta: 22. 4. 2014.

NKRJ = Национальный корпус русского языка http://www.ruscorpora.ru/ [НКРЯ] 


\section{PEЗЮME}

\section{ХОРВАТСКИЕ И РУССКИЕ ФРАЗЕОЛОГИЗМЫ С КОМПОНЕНТАМИ RЕР И ХВОСТ}

В работе дается сопоставительный анализ хорватских и русских фразеологизмов с компонентами rep и хвост. В первой части работы представлены выражения и фразеологизмы в широком смысле, основанные на переносном значении лексем гер и хвост. Во второй части работы внимание уделяется зоонимным фразеологизмам с компонентами rep и хвост, в которых проведена частичная или полная десемантизация, а фразеологизмы делятся на три группы, учитывая образ в глубинной структуре и мотивацию. Первая группа мотивированна образом животного и/или его хвоста. Для второй характерен факт, что в глубинной структуре животное, т.е. его хвост вступает в отношение с другим субъектом. Глубинная структура третьей группы основывается на модели поведения животных внутри группы.

Ключевые слова: хорватский язык, русский язык, фразеология, фразеологизмы с компонентами гер $и$ хвост 
